RESEARCH ARTICLE

\title{
EVALUATION OF COMMERCIAL ELISA, INDIRECT IMMUNOFLUORESCENCE TEST AND qPCR FOR THE DIAGNOSIS OF LEISHMANIA INFANTUM IN ASYMPTOMATIC DOGS FROM BOUIRA, NORTHEAST ALGERIA
}

\author{
Aicha Yasmine Bellatreche ${ }^{1,2}$,Hacene Medkour ${ }^{3}$, Radu Blaga ${ }^{2}$, Delphine Le Roux ${ }^{2}$, Kamel \\ Miroud $^{4}$, Khatima Ait-Oudhia ${ }^{1,5 *}$
}

${ }^{1}$ National Superior Veterinary School, Algiers, Algeria. Hasaq «Laboratory of Food Hygiene and Quality Assurance System»

${ }^{2}$ Umr Bipar, Inrae, Ecole Nationale Vétérinaire d'Alfort, Anses, Université Paris-Est, Maisons-Alfort, France

${ }^{3}$ Ihu Méditerranée Infection, MEФI, France; Aix-Marseille Université, IRD, APHM -19-21, France

${ }^{4}$ Laboratoire « Epidémio-surveillance, santé, productions et reproduction, expérimentation et thérapie cellulaire des animaux domestiques et sauvages (ESSPRETCADS)». Institut des Sciences Vétérinaires. Université Chadli Bendjedid El-Tarf, Algeria

${ }^{5}$ Laboratory of Biotechnology in Animal Reproduction, Blida, Algeria

\section{*Corresponding author:}

Prof. Dr. Khatima Ait-Oudhia

National Superior Veterinary School, rue Issad Abbes, El Alia, Oued Smar, Algiers, Algeria. HASAQ «Laboratory of Food Hygiene and Quality Assurance System»

Laboratory of Biotechnology in Animal Reproduction, Blida, Algeria

Phone: 00213540672395 .

ORCID: 0000-0002-2514-5615

E-mail: khatima.aitoudhia@gmail.com

Original submission:

31 August 2020

Revised submission:

26 October 2020

Accepted:

21 December 2020

\section{ABSTRACT}

Serological and molecular tests are important tools to determine and control Canine visceral leishmaniasis (CanL). The absence of pathognomonic symptoms and asymptomatic dogs make clinical diagnosis difficult. This study aims to determine the best combination for the diagnosis of Leishmania infantum in asymptomatic dogs. Ninety-four blood samples were collected from dogs in the province of Bouira, in Algeria and assessed with IFAT, ELISA, and qPCR. The sensitivity and specificity for each technique were evaluated in comparison with the indirect fluorescent antibody test (IFAT), which is considered the bestsuited test to determine the presence of $L$. infantum. In addition, the agreement between these tests was assessed. The use of Cohen's Kappa coefficient demonstrated a moderate agreement between IFAT and qPCR $(\mathrm{k}=0.475)$, and fair between the IFAT and ELISA $(\mathrm{k}=0.297)$. The sensitivity of the molecular test was higher $(55.56 \%)$ than that of the ELISA (33.33\%). According to those results, it is better to combine two tests for the diagnosis of CanL, especially in asymptomatic dogs, which is generally not included in the CanL control program.

Keywords: Canine visceral leishmaniasis, Leishmania infantum, zoonosis, diagnosis 


\section{INTRODUCTION}

Leishmaniasis is one of the most neglected diseases in the word. It occupies the third place of the most important vector-borne diseases after malaria and lymphatic filariasis (Inceboz, 2019), and is caused by an intracellular protozoan, Leishmania spp in mammals including humans. More than twenty species are belonging to the genus Leishmania (Bennai et al., 2018; WHO, 2020). For their transmission, Leishmania parasites involve a female Diptera from the family of Psychodidae, belonging to the Phlebotomus genus in the Old Word, and Lutzomiya genus in the New Word (Mouloua et al., 2017).

In humans, there is a wide variety of clinical forms of leishmaniasis. The most common in the world is cutaneous leishmaniasis (CL), local or diffuse, caused mainly by Leishmania major, L. tropica and $L$. infantum in the Old World, and generally by $L$. braziliensis, L. chagasi and L. Mexicana in the New World (De Vries et al., 2015). Visceral leishmaniasis (VL), known as kala azar, which can be fatal, is caused by L. donovani in Asia and Africa, and by L. infantum in the Mediterranean basin, South and Central America and in the Middle East and Central Asia (Dantas-Torres et al., 2019). The annual incidence of VL and CL has been estimated at 0.2 to 0.4 million cases and 0.7 to 1.2 million cases, respectively (Alvar et al., 2012). Another form of leishmaniasis deriving from kala azar, corresponds to the post kala azar dermal leishmaniasis (PKDL). It is caused by L. donovani. The mucocutaneous leishmaniasis (MCL) is the fourth form. It is caused by L. major and L. tropica (Inceboz, 2019).

Animals (dogs, cats, and rodents) play an important role in the transmission cycle of certain forms of leishmaniasis between them and secondary, to people, hence a zoonotic form (ZL).
Indeed, L. infantum is the common and important cause of canine leishmaniasis (CanL), which can be fatal to humans. There are at least 2.5 million infected dogs in the Mediterranean basin (Moreno and Alvar, 2002). The visceral, cutaneous and mucocutaneous leishmaniasis types can be found in canine species (Inceboz, 2019; Palumbo, 2010).

Dog constitutes the main reservoir/ host of $L$. infantum. It is frequently exposed to relapse after clinical recovery, which makes it a veritable target for reinforced and offensive preventive and vaccine prophylaxis, especially in endemic areas (Bourdoiseau, 2015). However, early diagnosis remains one of the means to control the infection. It is often based on the origin of the epidemic and clinical signs in dogs (Solano-Gallego et al., 2011). Moreover, the absence of pathognomonic symptoms and asymptomatic dogs makes clinical diagnosis of CanL difficult, which requires the use of laboratory techniques such as parasitological, immunological and molecular tests (Ribeiro et al., 2018). In veterinary medicine, molecular biology is increasingly used as a diagnostic tool because of its high sensitivity and specificity. Serological tests, such as the enzyme linked immunosorbent assay, are frequently used in epidemiological surveys (Ait-Oudhia et al., 2009). However, crossreactions with Leishmania species responsible for the cutaneous form and other haemoparasites constitute one of the limitations of serological tests (Ferreira et al., 2007; Porrozzi et al., 2007). In contrast, serological test can be very useful in some situations, such as in Brazil and to control CanL. Positive results of serological tests obtained for suspected dogs represent a criterion to indicate their euthanasia (Ribeiro et al., 2018). However, the absence of a gold standard test makes difficult the evaluation of the diagnostic methods for CanL (Solano-Gallego et al., 2014). Our epidemiological survey conducted in the district of Bouira aims 
to determine the best combination for detecting Leishmania infantum in asymptomatic dogs.

\section{MATERIALS AND METHODS}

\section{Sampling and study area}

The study was carried out in the district of Bouira $\left(36^{\circ} 17^{\prime} 0.708^{\prime \prime} \mathrm{N} 3^{\circ} 59^{\prime} 16.234\right.$ " E). It is located in Kabylia, where a rate of $36 \%$ of seropositive dogs by CanL has been recently reported (Medkour et al., 2020). The district of Bouira is characterized by a hot and dry climate in summer and cold and rainy in winter. The temperature varies from $0^{\circ} \mathrm{C}$ to $33^{\circ} \mathrm{C}$ and is rarely lower than $-4{ }^{\circ} \mathrm{C}$ or higher than $37^{\circ} \mathrm{C}$. The region has an annual precipitation of at least $432 \mathrm{~mm}$, for 216 days a year on average. The district of Bouira experiences a dry climate with estimated humidity of $69 \%$.

In the period from March to April 2019, 94 dogs (52 males and 42 females with 21 dogs younger than 12 months, 59 dogs between 12 months and 48 months and 14 dogs of 60 months and older) were randomly selected. Three groups of dogs were defined depending on their particular activities and functions: guard dogs $(n=19)$, farm $\operatorname{dogs}(n=7)$ and hunting dogs $(n=68)$. All samples were collected from apparently healthy dogs.

A volume of $6 \mathrm{ml}$ of blood was collected from the forelimb vein of each animal, and equally divided into EDTA and dry tubes. The separated sera were obtained by centrifugation of the clotting dry tube at $3000 \mathrm{~g}$ for $10 \mathrm{~min}$, then they were transferred to cryotubes. All samples were stored at $-20^{\circ} \mathrm{C}$ until analysis.

\section{Laboratory analysis}

The presence of $L$. infantum in asymptomatic dog samples was determined by serological and molecular tests. Indirect enzyme linked immunosorbent assay (ELISA) (ID screen Leishmaniasis Indirect, IDvet France) was realized in the UMR BIPAR (Maisons- Alfort, France), and the indirect immunofluorescence intibody test (IFAT) and molecular assays (qPCR) were realized at the Institut Hospitalier Universitaire IHUMediterranée Infection laboratory, Marseille, France. The doubtful results are considered negative.

\section{Serological assays}

For ELISA, following the manufacturer's instructions, 96 well plate pre-coated with $L$. infantum-purified antigen were incubated 45 minutes $\pm 5 \mathrm{~min}$ at $37^{\circ} \mathrm{C}$ with $\operatorname{dog}$ sera and standards, all diluted at $1 / 10$ in sample buffer. After incubation, the plates were washed three times with wash buffer, and coated with an antidog IgG- peroxidase (HRP) conjugate diluted in a sample buffer. A second incubation was realized for 30 minutes at $37^{\circ} \mathrm{C}$. The microwells were then washed three times and a reaction was revealed using a substrate solution (TMB) and the colorimetric reaction was terminated by stop solution. The plates were read at $450 \mathrm{~nm}$, on the Multiskan fc reader and analyzed with Skanit Research Edition 4.1 software. For each sample, the $\mathrm{S} / \mathrm{P}$ percentage was calculated according to the formula:

$$
S P \%=\frac{\text { OD sample-ODNC }}{\text { OD } P C-O D N C} \times 100 .
$$

The interpretation of canine sera is as follows:

a positive result: $\quad S P \% \geq 50 \%$;

a doubtful result: $40 \%<S P \%<50 \%$;

a negative result: $S P \% \leq 40 \%$. 
Samples were also analyzed by IFAT, which is used to detect $L$. infantum specific antibodies. Coated plates with $L$. infantum commercial antigens (Zoetis, France) were incubated with diluted sera at $1: 50$ for $30 \mathrm{~min}$ at $37^{\circ} \mathrm{C}$. After incubation, they were washed twice with PBS and once with distilled water. Then IgG anti-dog conjugated with fluorescein isothiocyanate (FITC) (Jackson ImmunoResearch Europe Ltd. Cambridge House, UK) was added into each microwell after dilution at 1:200. A second incubation for $30 \mathrm{~min}$ at $37^{\circ} \mathrm{C}$ was done in the dark. The washing procedure was repeated as described above. Some drops of mounting medium Fluoprep (bioMérieux, France) were added on the coverslips to read plates using a fluorescence microscope. Positive and negative controls had been added to validate the results. Positive control was a known serum of French dog infected by $L$. infantum (at the dilution 1:1600), and negative control was a known serum of dog non-infected by Leishmania species from IHUMéditerranée Infection lab collection. All samples were examined by two different investigators to confirm observations. Samples were considered positive at 1:50 dilution, and all positive samples positive results were further investigated using serial dilution at 1:100, and 1:200, 1:400, 1:800 and 1:1600. Positive sera at dilution of $1: 1600$ were considered highly positive.

\section{Molecular assays}

DNA was extracted from $200 \mu \mathrm{l}$ of dog blood samples using a commercial DNA extraction kit (QIAmp DNA Mini Kit ${ }_{\overparen{B}}$, (Qiagen,Courtaboeuf, France) and performed on BIOROBOT EZI (Qiagen, Courtaboeuf, France) per the manufacturer's recommendations. The extracted DNA was eluted in $200 \mu$ l of distilled water and then stored at $-20{ }^{\circ} \mathrm{C}$. All samples were screened using a qPCR targeting the $18 \mathrm{~S}$ rRNA gene of Leishmania spp (Medkour et al. 2020) as well as specific $L$. infantum qPCR targeting the kinetoplast DNA (kDNA) (Mary et al., 2004). qPCR reactions were performed in a final volume of $20 \mu \mathrm{l}$ including $10 \mu \mathrm{l}$ of Eurogentec Master Mix Roche, $3 \mu \mathrm{l}$ of distilled water DNAse and RNAse free, 0,5 $\mu \mathrm{l}$ FAM- labeled probe (concentrated at $5 \mu \mathrm{M}), 0.5 \mu \mathrm{l}$ for each forward and reverse primers (concentrated at $20 \mu \mathrm{M}$ ), $0.5 \mu 1$ of UDG and $5 \mu 1$ of the DNA template. The amplification was performed in a CFX96 Real-Time System (Bio-Rad Laboratories, Foster City, CA, USA) according to Roche Protocol: incubation at $50^{\circ} \mathrm{C}$ for two minutes, 40 cycles of denaturation at 95 ${ }^{\circ} \mathrm{C}$ for $5 \mathrm{~s}$ and annealing-extension at $60{ }^{\circ} \mathrm{C}$ for $30 \mathrm{~s}$. These two steps are preceded by the first denaturation for 5 minutes, at $95{ }^{\circ} \mathrm{C}$. Known Leishmania DNAs were added as positive control and master mixture was added as negative control. Samples were considered positive when the cycle threshold $(\mathrm{Ct})$ waslower than 38 .

\section{Statistical analysis}

Statistical analyses were performed using XLSTAT (V 2020.3.1). The accuracy parameters of the assays (sensitivity, specificity, positive predictive value and negative predictive value) were calculated using two-by-two contingency tables, and IFAT was considered the best-suited test. The $\chi^{2}$ test was calculated to determine if a difference in efficiency exists and $\mathrm{p}<0.05$ was considered significant. The agreement between ELISA, IFAT and qPCR to detect $L$. infantum was evaluated by the use of Cohen's Kappa coefficient (k). The strength of the agreement between these techniques is assessed as follows: no agreement $(<$ 0 ), slight agreement $(0-0.2)$, fair agreement (0.2$0.4)$, moderate agreement (0.4- 0.6), substantial agreement (0.6- 0.8) and almost perfect agreement $(0.8-1)$ (Landis and Koch, 1977). 


\section{RESULTS}

All samples were randomly selected from 94 dogs living in an endemic area of CanL and tested using ELISA, IFAT and qPCR. The comparative test parameters (sensitivity, specificity, positive and negative predictive values) were calculated and represented in Table 2.

Of the 94 samples, 17 (18\%) were positive by ELISA, $9(10 \%)$ were positive by IFAT and $3(3 \%)$ by qPCR (Table 1$)$.
The IFAT has resulted in different IgG titers: $3.19 \%$ (3/94) were positive at 1:50 dilution; $4.26 \%(4 / 94)$ were positive at 1:100 dilution; $1.06 \%(1 / 94)$ was positive at 1:200 and only $1.06 \%$ (1/94) was positive at 1:400 dilution.

When considering IFAT as a reference test, 5/94 (5.32\%) were positive with both IFAT and ELISA, and 4/94 (4.26\%) were positive with IFAT but negative with ELISA. Only 3/94 (3.19\%) were positive with both IFAT and qPCR. Eighty-five samples were negative when comparing IFAT and qPCR, and 73/ 94 were negative when comparing IFAT and ELISA (Table 1).

Table 1 Contingency table for the detection of $L$. infantum antibodies in dogs' sera by commercial ELISA and qPCR in comparison with IFAT $(n=94)$

\begin{tabular}{|c|c|c|c|c|c|}
\hline & & IFAT & & & \\
\hline & & Positive & Negative & Total & $\%$ \\
\hline \multirow{3}{*}{ Elisa } & Positive & 5 & 12 & 17 & $17(18 \%)$ \\
\hline & Negative & 4 & 73 & 77 & $77(82 \%)$ \\
\hline & & $9(10 \%)$ & $85(90 \%)$ & 94 & \\
\hline \multirow{3}{*}{ qPCR } & Positive & 3 & 0 & 3 & $3(3 \%)$ \\
\hline & Negative & 6 & 85 & 91 & $91(97 \%)$ \\
\hline & & $9(10 \%)$ & $85(90 \%)$ & 94 & \\
\hline
\end{tabular}

A moderate agreement in detecting L. infantum in dogs was reached between IFAT and qPCR $(\mathrm{k}=$ 0.475). However, the results indicate a fair level agreement between IFAT and ELISA $(\mathrm{k}=0.297)$. In both cases, we found a statistically significant difference between these methods $\left(\chi^{2}>3.841, \mathrm{P}<\right.$ 0.05 (Table 2).
The results of the diagnostic performance of tests are described in Table 2 . The sensitivity and specificity of ELISA were $55.56 \%$ and $85.88 \%$, respectively. qPCR obtained a high specificity (100\%).

The positive predictive values (PPV) were $29.41 \%$ and $100 \%$ with ELISA and qPCR, respectively, and the negative predictive values (NPV) were $94.81 \%$ and $93.41 \%$ with ELISA and qPCR, respectively. 
Table 2 Results of diagnostic performance of ELISA and qPCR for detection of $L$. infantum in asymptomatic dogs in comparison with IFAT

\begin{tabular}{lll}
\hline & ELISA & qPCR \\
\hline Sensitivity (\%) & 55.56 & 33.33 \\
\hline Specificity (\%) & 85.88 & 100 \\
\hline Positive predictive value (\%) & 29.41 & 100 \\
\hline Negative predictive value (\%) & 94.81 & 93.41 \\
\hline Kappa coefficient & 0.297 & 0.475 \\
\hline P value & $<0.002$ & $<0.0001$ \\
\hline$\chi^{2}$ & 9.43 & 29.27 \\
\hline
\end{tabular}

\section{DISCUSSION AND CONCLUSION}

The Mediterranean Basin, including Algeria, is an endemic area for visceral leishmaniasis, and dogs constitute a potential reservoir for humans (Bourdoiseau, 2015). The geographical position and the climate of the district of Bouira maintain the cycle of $L$. infantum. Samples were collected from rural areas, where water points are frequent. In Algeria, the sand fly vectors are represented mainly by Phlebotomus perniciosus and $P$. longicuspis (Izri et al., 1990; Killick-Kendrick, 1990)

In most cases CanL is either asymptomatic or accompanied by no specific symptoms, which make a diagnosis difficult (Ribeiro et al., 2018). In those cases, laboratory techniques are requested to determine the infection by $L$. infantum. In this study, we aimed to evaluate the sensitivity and specificity of ELISA and qPCR in comparison with IFAT as a reference test to determine the best combination for detecting $L$. infantum infection in asymptomatic dogs. The randomly selected dogs were living in an endemic area of CanL.

All parasitological, serological and molecular tests need to be interpreted according to their limits and advantages (Ribeiro et al., 2018). Some studies consider that IFAT is a technical reference in diagnostic laboratory practices (Paltrinieri et al., 2010). It is commonly used as the best-suited test in clinical and research studies (Maia and Campino, 2008; Solano-Gallego et al., 2009). In some Latin American countries such as Colombia and Brazil, IFAT is considered the reference test to determine the presence of Leishmania-specific antibodies (Herrera et al., 2019). However, even if IFAT is one of the most common serological tests, the study of Persichetti et al. (2017) suggested that the diagnosis of clinical leishmaniasis with ELISA was better than with IFAT. Besides, with IFAT a cross-reaction between Leishmania Spp and Trypanosoma cruzi can occur (Luciano et al., 2009).

In our study, ELISA technique showed a moderate sensitivity (55.56 \%) against $33.33 \%$ of qPCR in comparison to IFAT. However, the specificity of ELISA was much lower (85.88\%) than that of qPCR $(100 \%)$. According to the results of Wang et al. (2011), molecular assays are more sensitive than ELISA, remaining the most suitable test for L. infantum diagnosis in blood samples, more suitable than serological tests in asymptomatic 
dogs. PPV and NPV were analyzed to evaluate the effectiveness of the diagnostic tools used in this study. These parameters are affected by sensitivity and specificity of tests (Surawicz and Travel, 2008). According to our results, PPV of qPCR was optimal (100\%), with the specificity of $100 \%$ compared to ELISA (Table 2), which suggest that qPCR can be the best tool to detect $L$. infantum in asymptomatic dog samples. Further studies with a large number of samples are needed, especially in asymptomatic dogs because most studies were performed in clinically infected dogs, which make our results inconclusive.

In many endemic areas, the vaccination is induced against leishmaniasis. In Brazil, euthanasia is recommended for infected and seropositive dogs (Ribeiro et al., 2018). Serological tests cannot distinguish between vaccinated and naturally infected dogs, unlike the molecular approach, which is more relevant than serological tests (Marcondes et al., 2013).

In another study carried out on thirty-four dogs with skin lesions evoking American Tegumentary Leishmaniasis (ATL) in an endemic area of the state of Rio de Janeiro, it was suggested that ELISA was more sensitive to detect specific antiLeishmania IgG with sensitivity and specificity of 97.1\% (Ribeiro et al., 2007). Thus, the sensitivity and specificity may be different between several diagnostic tests. According to Camargo et al. (2010), even if the PCR technique is in huge demand for the diagnosis of CanL due to its high accuracy, this technique can reveal false-negative results in some cases. This study showed that the specificity of qPCR was $100 \%$, but it proved less sensitive. Despite this conclusion, molecular techniques are characterized by high sensitivity and specificity, and they are commonly used in veterinary diagnosis routine with the use of several biological samples, for instance, skin fragments, lymph node puncture and vein blood samples (Silva et al., 2017; Solano-Gallego et al., 2007; SolanoGallego et al., 2011). However, blood samples are best analyzed with PCR for $L$. infantum diagnosis. Moreover, molecular assays have a non-invasive access to the sample (Wang et al., 2011).

A moderate agreement between IFAT and qPCR $(\mathrm{k}=0.475)$ and a fair agreement between IFAT and ELISA (0.297) were measured. In the study of Ferreira et al. (2007), the agreement between ELISA and IFAT was satisfactory, which can mean that test agreement depends on various parameters, as it was mentioned by Dye et al. (1993). Ferreira et al. (2007) reported that in 20 $\%$ of detected cases of CanL during the incubation period or seroconversion, the levels of antibodies could be variable, which explained the low level of agreement between the serological tests used for the detection of asymptomatic dogs. The specificity of $100 \%$ for serological test was showed and ELISA proved more sensitive than IFAT (Ferreira et al., 2007).

Sensitivity and specificity can differ between the studies. Several factors can be at the origin of these variabilities such as the type of antigen or the protocol followed when using certain tools (Sundar and Rai, 2002). In all cases, further studies are needed to improve the sensitivity of the diagnostic tests for canine leishmaniasis, especially in asymptomatic dogs (Silva et al., 2014). Away from all appreciations about descriptive test parameters, asymptomatic dogs can be an infective source of sandflies and can therefore transmit the infection to humans (Alvar et al., 1994; Soares et al., 2011; Wang et al., 2011). Actually, the skin is the main target of sandflies. It is the site of inoculation of Lesihmania spp, which has been isolated from intact skin (Madeira et al., 2009; Silva et al., 2016). The incubation period for CanL is variable and can last from few months to several years (Reiner and 
Locksley, 1995). After the incubation period, the dogs can remain asymptomatic and resistant to leishmaniasis, or they present with clinical signs such as the skin lesions, and can die if not cured (Dye et al., 1992). The sand fly takes its blood meal in the host from the skin, which is sufficiently irrigated, especially in the auricular region (Travi et al., 2001). It was demonstrated by Laurenti et al. (2013) that asymptomatic dogs were more infective to the Diptera female than symptomatic dogs, which could explain the possibility of transmission of Leishmania spp from dogs without clinical lesions, especially in an endemic area. The same authors reported the results of xenodiagnoses which showed a high proportion of infection by Leishmania infantum chagas iin vectors $(38.5 \%$ ) that fed on asymptomatic dogs in comparison with the Phlebotomines that fed on symptomatic dogs (24.7\%). In addition, the study demonstrated that five asymptomatic dogs among 14 examined by immunohistochemistry presented parasites in their skin.

With these conclusions and according to Madeira et al. (2009), asymptomatic dogs are considered a potential source of infection of sandflies, and can maintain the epidemiological cycle of CanL.

This study highlights for the first time $L$. infantum in asymptomatic dogs from Algeria, suggesting their involvement in the epidemiological cycle

\section{REFERENCES}

Alvar J, Molina R, San Andrés M, Tesouro M, Nieto J, Vitutia M, et al. 1994. Canine leishmaniasis: clinical, parasitological and entomological follow-up after chemotherapy. Annals of Tropical Medicine \& Parasitology, 88 (4), 371-378. doi.org/1 $0.1080 / 00034983.1994 .11812879$ of the parasite, especially in an endemic area. According to our results, IFAT had a moderate agreement with qPCR for detecting Leishmania infantum antibodies in sera from dogs compared to ELISA, but the sensitivity was not as good. In epidemiological surveys and for the reliable results, especially in asymptomatic dogs, it is better to combine two tests for the screening and diagnostic of CanL. Serological and molecular tests are very helpful and widely used to determine and control the Leishmania infection, but serological tests remain more practical and easier to use. The choice of diagnostic tools depends on several parameters, including their sensitivity and specificity.

\section{ACKNOWLEDGEMENTS}

Authors thank veterinarians and dog owners for their help in collecting samples. We thank dr. Mohamed Yehya Elamin AISSIOU (from ESSAIA, Algiers, Algeria) and Mrs. Caroline TRAN VAN (Head of English Department from University of Paris- Est, Créteil (France) for critical reading of the manuscript. We thank also IDvet for providing Kit ELISA for the fast analysis of dog samples.

\section{CONFLICT OF INTEREST}

\section{None}

Alvar J, Vélez ID, Bern C, Herrero M, Desjeux P, Cano J, et al. 2012. Leishmaniasis worldwide and global estimates of its incidence. PLoS ONE, 7 (5), e35671.doi.org .doi.org/10.1371/ journal.pone.0035671

Ait-Oudhia K, Lami P, Lesceu S, Harrat Z, Hamrioui B, Dedet JP, et al. 2009. Increase in the prevalence of canine leishmaniasis in urban Algiers (Algeria) following the 2003 earthquake. Annals Of Tropical Medicine And Parasitology, 103(8), 679-692. doi:10.1179/000349809X12554106963591 
Bennai K, Tahir D, Lafri I, Bendjaballah-Laliam A, Bitam I, Parola P.2018. Molecular detection of Leishmania infantum DNA and host blood meal identification in Phlebotomus in a hypoendemic focus of human leishmaniasis in northern Algeria. PLoS Neglected Tropical diseases,12(6), e0006513. doi.org/10.1371/journal.pntd.0006513.

Bourdoiseau G.2015. La leishmaniose canine à Leishmania Infantum actualités épidémiologiques - applications. Bulletin de l'Académie Vétérinaire de France. doi. org/10.4267/2042/56543

Camargo JB, Langoni H, Troncarelli MZ, Machado JG, Lucheis SB, Padovani CR. 2010. Performance of IFAT, ELISA, direct parasitological examination and PCR on lymph node aspirates for canine visceral leishmaniasis diagnosis. Journal of Venomous Animals and Toxins including Tropical Disesases, 16, 414-420. doi.org/10.1590/S167891992010000300007

De Vries HJC, Reedijk SH, Schallig HDFH. 2015. Cutaneous Leishmaniasis: Recent Developments in Diagnosis and Management. American Journal of Clinical Dermatology, 6, 99-109. doi.org/10.1007/s40257-015-0114-Z

Dantas-Torres F, Miró G, Baneth G, Bourdeau P, Breitschwerdt E, Capelli G, et al. 2019. Canine Leishmaniasis Control in the Context of One Health.Emerging Infectious Diseases, 25, (12). doi.org/10.3201/eid2512.190164

Dye C, Killick- Kendrick R, Vitutia MM, Walton R, KillickKendrick M, Harith AE, et al. 1992. Epidemiology of canine leishmaniasis: prevalence, incidence and basic reproduction number calculated from cross-sectional serological survey on the island of Gozo, Malta. Parasitology, 105(1), 35-41. doi:10.1017/S0031182000073662

Dye C, Vidor E, Dereure J. 1993. Serological diagnosis of leishmaniasis: On detecting infection well as disease. Epidemiology \& Infection, 110(3), 647-656. doi.10. 1017/ S0950268800051074.

Ferreira de Castro E, de Lana M, Carneiro M, Reis AB, Paes DV, da Silva ES, el al. 2007. Comparison of serological assays for the diagnosis of canine visceral leishmaniasis in animals presenting different clinical manifestations. Veterinary \& Parasitology, 146, 235-241. doi.org/10.1016/j. vetpar.2007.02.015

Herrera G, Castillo A, Ayala MS, Flórez C, Cantillo-Barraza O, Ramirez JD.2019. Evaluation of four rapid diagnostic tests for canine and human visceral Leishmaniasis in Colombia. BMC Infectious Diseases, 19(1), 747. doi.org/10.1186/ s12879-019-4353-0

Inceboz T. 2019. Epidemiology and Ecology of Leishmaniasis. In Current Topics in Neglected Tropical Diseases. IntechOpen. doi.org/10.5772/intechopen.86359

Izri MA, Belazzoug S, Boudjebla Y, Dereure J, Pratlong S, Delalbre-Belmonte A, et al. 1990. Leishmania infantum MON-1 isolated from Phlebotomus perniciosus in Kabylia
(Algeria). Annales de Parasitologie humaine et comparée, 65 (3), 151-152.

Killick-Kendrick R. 1990. Phlebotomine vectors of the leishmaniases: a review. Medical and Veterinary Entomology, 4(1), 1- 24. doi.org/10.1111/j.1365-2915.1990.tb00255.x

Landis JR, Koch GG. 1977. The measurement of observer agreement for categorical data. Biometrics, 33(1), 159-74.

Laurenti MD, Rossi CN, da Matta VLR, Tomokane TY, Corbett CEP, Secundino NFC, et al.2013. Asymptomatic dogs are highly competent to transmit Leishmania (Leishmania) infantum chagasi to the natural vector. Veterinary Parasitology, 196 (3-4), 296- 300. doi.org/10.1016/j.vetpar.2013.03.017

Luciano RM, Lucheis SB, Troncarelli MZ, Luciano DM, Langoni H.2009. Cross reaction evaluation of Leishmania spp and Trypanosoma cruzi antigens in dogs' serologic response by indirect immunofluorescence test (IIF). Brazilian Journal of Veterinary Research and Animal Science, 46 (3). doi. org/10.11606/issn.1678-4456.bivras.2009.26765

Madeira MF, Figueiredo FB, Pinto AGS, Nascimento LD, Furtado M, Mouta- Confort E, et al. 2009. Parasitological diagnosis of canine visceral leishmaniasis: is intact skin a good target?. Research in Veterinary Science, 87(2), 260-262. doi.org/10.1016/j.rvsc.2009.03.008

Maia C, Campino L. 2008. Methods for diagnosis of canine leishmaniasis and immune response to infection. Veterinary parasitology, 158(4), 274-287. doi.org/10.1016/j. vetpar.2008.07.028

Marcondes M, de Lima VMF, de Araújo MDFL, Hiramoto RM, Tolezano JE, Vieira RFC, et al. 2013. Longitudinal analysis of serological tests officially adopted by the Brazilian Ministry of Health for the diagnosis of canine visceral leishmaniasis in dogs vaccinated with Leishmune ${ }^{\circledR}$. Veterinary \& Parasitology, 197 (3-4), 649-652. doi.org/10.1016/j.vetpar.2013.07.013

Mary C, Faraut F, Lascombe L, Dumon H. 2004. Quantification of Leishmania infantum DNA by a Real-Time PCR Assay with High Sensitivity. Journal of Clinical Microbiology, 42(11), 5249-5255. doi.org/10.1128/JCM.42.11.5249-5255.2004

Medkour H, Laidoudi Y, Lafri I, Davoust B, Mekroud A, Bitam I, et al. 2020. Canine vector-borne protozoa: Molecular and serological investigation for Leishmania spp., Trypanosoma spp., Babesia spp., and Hepatozoon spp. in dogs from Northern Algeria. Veterinary \&. Parasitology: Regional Studies and Reports, 19, 100353. doi.org/10.1016/j. vprsr.2019.100353

Moreno J,AlvarJ. 2002. Canine leishmaniasis: epidemiological risk and the experimental model. Trends in Parasitoly, 18(9), 399-405. doi.org/10.1016/s1471-4922(02)02347-4

Mouloua A, Boubidi SC, Boubia L, Mezai G, Madiou M, Harrat Z. 2017. Impact Environnemental Sur La Répartition Des Leishmanioses Dans Le Foyer De Tizi-Ouzou (Algérie). Revue Médecine Vétérinaire, 168 (10-2), 252-261. 
Paltrinieri S, Solano-Gallego L, Fondati A, Lubas G, Gradoni L, Castagnaro M, et al. 2010. Guidelines for diagnosis and clinical classification of leishmaniasis in dogs. Journal of the American Veterinary Medical Association, 236(11), 11841191. doi.org/10.2460/javma.236.11.1184

Palumbo E. 2010. Treatment Strategies for Mucocutaneous Leishmaniasis. Journal of Global Infectious Diseases, 2(2), 147-150.doi.org/10.4103/0974-777X.62879

Persichetti MF, Solano-Gallego L, Vullo A, Masucci M, Marty P, Delaunay P, et al. 2017. Diagnostic performance of ELISA, IFAT and Western blot for the detection of anti-Leishmania infantum antibodies in cats using a Bayesian analysis without a gold standard. Parasites \& Vectors, 10 (1). doi.org/10.1186/ s13071-017-2046-3

Porrozzi R, Santos da Costa MV, Teva A, Falqueto A, Ferreira AL, dos Santos CD et al. 2007. Comparative Evaluation of Enzyme-Linked Immunosorbent Assays Based on Crude and Recombinant Leishmanial Antigens for Serodiagnosis of Symptomatic and Asymptomatic Leishmania infantum Visceral Infections in Dogs. Clinical and Vaccine Immunology,14(5), 544-548. doi.org/10.1128/CVI.00420-06

Reiner SL, Locksley RM. 1995. The regulation of immunity to Leishmania major. Annual review of immunology, 13 (1), 151-177. doi.org/10.1146/annurev.iy.13.040195.001055

Ribeiro F, Schubach A, Mouta-Confort E, Schubach T, Madeira M, Marzochi M.2007. Use of ELISA employing Leishmania (Viannia) braziliensis and Leishmania (Leishmania) chagasi antigens for the detection of $\operatorname{IgG}$ and $\operatorname{IgG} 1$ and IgG2 subclasses in the diagnosis of American tegumentary leishmaniasis in dogs. Veterinary \& Parasitology, 148, 200-6. doi.org/10.1016/j.vetpar.2007.06.034

Ribeiro RR, Michalick MSM, da Silva ME, dos Santos CCP, Frézard FJG, da Silva SM. 2018. Canine Leishmaniasis: An Overview of the Current Status and Strategies for Control. BioMed Research International, 2018, 1-12. doi. org/10.1155/2018/3296893

Silva DTD, Starke-Buzetti WA, Alves-Martin MF, Paixão MDS, Tenório MDS, Lopes MLM. 2014. Comparative evaluation of several methods for Canine Visceral Leishmaniasis diagnosis. Revista Brasileira de Parasitologia Veterinária, 23(2), 179-186. doi.org/10.1590/S198429612014033

Silva FMDM, Santos EMDS, Torres SM, Yamasak EM, Ramos RAN, Alves LC, et al. 2016. Parasite load in intact and ulcerative skin of dogs with leishmaniasis. Revista Brasileira de Parasitologia Veterinari, 25, 127-130. doi.org/10.1590/ S1984-29612016014

Silva RC, Richini-Pereira VB, Kikuti M, Marson PM, Langoni H. 2017. Detection of Leishmania (L.) infantum in stray dogs by molecular techniques with sensitive speciesspecific primers. Veterinary Quarterly,37(1), 23-30. doi.org/ $10.1080 / 01652176.2016 .1252073$
Soares MRA, de Mendonça IL, do Bonfim JM , Rodrigues JA, Werneck GL, Costa CHN. 2011. Canine visceral leishmaniasis in Teresina, Brazil: Relationship between clinical features and infectivity for sand flies. Acta Tropica, 117(1), 6-9. doi. org/10.1016/j.actatropica.2010.08.015

Solano-Gallego L, Rodriguez-Cortes A, Trotta M, Zampieron C, Razia L, Furlanello T, et al. 2007. Detection of Leishmania infantum DNA by fret-based real-time PCR in urine from dogs with natural clinical leishmaniosis. Veterinary Parasitology, 147, 315-319. doi.org/10.1016/j.vetpar.2007.04.013

Solano-Gallego L, Koutinas A, Miró G, Cardoso L, Pennisi MG, Ferrer L, et al. 2009. Directions for the diagnosis, clinical staging, treatment and prevention of canine leishmaniosis. Veterinary parasitology, 165(1-2),1-8.d oi.org/10.1016/j. vetpar.2009.05.022

Solano-Gallego L, Miró G, Koutinas A, Cardoso L, Pennisi MG, Ferrer L, et al. 2011. LeishVet guidelines for the practical management of canine leishmaniosis. Parasites \& Vectors, 4(1), 86. doi.org/10.1186/1756-3305-4-86

Solano-Gallego L, Villanueva-Saz S, Carbonell M, Trotta M, Fulanello T, Natale A. 2014. Serological diagnosis of canine leishmaniosis: comparison of three commercial ELISA tests (Leiscan ${ }^{\circledR}$, ID Screen ${ }^{\circledR}$ and leishmania $96{ }^{\circledR}$ ), a rapid test (Speed leish K ()) and an in-house IFAT. Parasites \& Vectors, 7(1),111. doi. org/10.1186/1756-3305-7-111

Sundar S, Rai M. 2002. Laboratory diagnosis of visceral leishmaniasis. Clinical and diagnostic laboratory immunology, 9, 951-958. doi.org/10.1128/CDLI.9.5.951-958.2002

Surawicz B, Travel M. 2008. Stress test. In Chou's electrocardiography in clinical practice, 221- 255. WB Saunders.

Travi BL, Tabares CJ, Cadena H, Ferro C, Osorio Y. 2001. Canine Visceral Leishmaniasis in Colombia: relationship between clinical and parasitological status and infectivity for sand flies. The American Society of Tropical Medicine and Hygiene, 64 (3-4), 119-124. doi.org/10.4269/ ajtmh.2001.64.119

Wang JY, Ha Y, Gao CH, Wang Y, Yang YT, Chen HT. 2011. The prevalence of canine Leishmania infantum infection in western China detected by PCR and serological tests. Parasites \&Vectors, 4(69). doi.org/10.1186/1756-3305-4-69

WHO. 2020. Leishmaniasis. URL Https://Www.Who.Int/ News-Room/Fact-Sheets/Detail/Leishmaniasis.(accessed 4.5.2020) 


\section{EVALUACIJA KOMERCIJALNOG ELISA TESTA, INDIREKTNOG IMUNOFLUORESCENTNOG TESTA I qPCR U DIJAGNOSTICI LEISHMANIAE INFANTUM KOD ASIMPTOMATSKIH PASA IZ BOUIRAE NA SJEVEROISTOKU ALŽIRA}

\section{SAŽETAK}

Serološki i molekularni testovi predstavljaju važno sredstvo u određivanju i kontroli pseće visceralne lišmanijaze (CanL). Odsustvo patognomoničnih simptoma i asimptomatski psi otežavaju postavljanje dijagnoze kliničkim putem. Cilj ovog istraživanja jeste odrediti najbolju kombinaciju za dijagnosticiranje Leishmaniae infantum kod asimptomatskih pasa. Devedeset i četiri krvna uzorka su prikupljena od pasa u provinciji Bouira u Alžiru nakon čega su analizirani IFAT, ELISA i qPCR metodom. Senzitivnost i specifičnost svake od metoda je evaluirana u usporedbi s indirektnim testom fluorescentnim antitijelima (IFAT) koji se smatra najboljim za određivanje prisustva L. infantum. Pored toga se procjenjuje i slaganje između ovih testova. Korištenjem Cohen Kappa koeficijenta je pronađeno umjereno slaganje između IFAT testa i qPCR $(\mathrm{k}=0.475)$ i slabo slaganje između IFAT I ELISA testova $(\mathrm{k}=0.297)$. Dokazana je veća senzitivnost molekularnog testa $(55.56 \%) \mathrm{u}$ odnosu na ELISA test (33.33\%). Rezultati našeg istraživanja pokazuju da je za dijagnosticiranje CanL, posebno kod asimptomatskih pasa, bolje kombinirati dva testa, što obično nije uključeno u kontrolni program CanL.

Ključne riječi: Pseća visceralna lišmanijaza, Leishmania infantum, zoonoza, dijagnoza 